\title{
Choice of Anchor Currencies and Dynamic Preferences for Exchange Rate Pegging in Asia
}

\author{
Syed Kumail Abbas Rizvi*, Bushra Naqvi** and Nawazish \\ Mirza $^{* * *}$
}

\begin{abstract}
This paper attempts to answer two important questions in the context of Asian exchange rate regimes with respect to the choice of anchor currencies and dynamic preferences for exchange rate pegging. According to our results, the US dollar is the first choice of a de facto peg for many countries such as China, Hong Kong, the Philippines, and Pakistan. Other countries, apart from Korea and Indonesia, seem to prefer a basket peg comprising two or more anchor currencies with rapidly increasing weight attached to the euro. This shift from the US dollar to the euro reflects changes in the choices, preferences, and policies of these economies as a result of varying macroeconomic and global financial realities.
\end{abstract}

Keywords: Exchange rate regime, flexibility, pegging, Asia.

JEL classification: E42, E58, F31, F33, F41.

\section{Introduction}

Despite its several demerits, exchange rate pegging has remained the most popular exchange rate regime for many countries, particularly during the 1990s when formulating their external financial policies. Undoubtedly, it has played a significantly constructive role in the development of several economies across the globe. It was common practice for developing countries with less stable currencies to create a currency peg with a more stable currency to achieve a variety of benefits including but not limited to stable inflation, monetary policy discipline, and control over trade deficits.

Pegged exchange rates have different forms, including unilateral pegs, multilateral pegs, currency unions, and currency boards. In a unilateral peg, an individual country decides on the basis of its indigenous

\footnotetext{
* Associate Professor of Finance, Lahore School of Economics.

** Assistant Professor of Finance, Lahore University of Management Sciences.

*** Associate Professor of Finance, Lahore School of Economics.
} 
and unique circumstances to peg its domestic currency to a single anchor currency. The domestic country sets its own monetary policy, which is similar to that of the anchor currency country, and tries to target different monetary variables such as inflation, credit expansion, and the interest rate in the currency of the anchor country.

A more rigid form of the unilateral peg-in which the country establishing a peg is prepared to lose its monetary independence by sacrificing its ability to decide the size of its monetary base-might be categorized as a currency board. Multilateral pegs and currency unions are arrangements where several countries jointly agree to follow specific sets of exchange rate parities. The responsibility for protecting the parity and intervening if needed is shared by all member countries. Multilateral pegs can be better understood by looking at the monetary system of the European Union before and after the adoption of a unified currency and a single monetary policy (Dueker \& Fischer, 2001).

There are various pros and cons of pegged exchange rate regimes. On one hand, such a regime is extremely beneficial because it serves as a tool for keeping inflation under control and provides policymakers with discipline. On the other hand, it has certain disadvantages when it curtails the freedom of an autonomous monetary policy and increases the country's exposure to shocks and speculative attacks transmitted from the anchor country. It also binds policymakers to pursuing any anti-inflationary measures and potentially exposes the country to financial crises by making it financially fragile (Mishkin, 1998).

However, the sole fact of being a pegged exchange rate regime does not make a country vulnerable to financial crisis and fragility. Other macroeconomic factors also play a role in making an economy vulnerable. These factors include the associated monetary structure, inconsistencies in the exchange rate policy itself, supplementary macroeconomic policies, futile policy execution, the failure to practice effective structural and macroeconomic policies that might have fortified the financial system, and the pursuit of hasty disinflation and obstinacy in managing shocks (Bubula \& Otker-Robe, 2003).

Hard pegs may seem a viable option for countries with a weak monetary system, but they are certainly not a cure that can be applied to every economy. A country that wishes to adopt a hard peg must be able to meet the following criteria: an optimum currency region, a large portion of its total trade should be with the anchor currency's country, its inflation 
preferences should be similar to those of the anchor country, flexible labor markets, and a strong commitment to following the regulations.

It is also very important to find the right peg, i.e., one that ties the domestic country to the right anchor currency. For example, if the home country has diverse trade partners, pegging its currency to a basket of currencies would be a more viable option than pegging it to a single currency (Velasco, 1999). The rule is, nevertheless, to keep the basket simple, observable, and transparent because a multifaceted and fluctuating basket system can lead to added complexities.

When countries adopt a basket peg, they must also be ready to disclose certain facts to the public such as what currencies they have included in the basket, what individual weights are assigned to each country, and why and how often they will change the corresponding weights. At times, governments choose not to share this crucial information because of the pressure exerted by political and international financial institutions.

Following primarily the methodology proposed by Frankel and Wei (1994), this paper has two aims: (i) to determine the most popular anchor currency for different Asian economies by analyzing the degree of pegging and estimating the implicit weights that different countries assign to that anchor currency or currencies; and (ii) to examine the dynamic behavior of these implicit weights, reflecting changes in the choices, preferences, or policies of these economies as a result of varying macroeconomic and global financial realities. Our findings generally acknowledge the undeterred importance of the US dollar as the most favored anchor currency for many South Asian countries. However, we also find the euro receiving more attention in several countries when assigning weights to basket anchor currencies.

Section 2 provides a description of the data used and sample countries. Section 3 describes the methodology used. Section 4 presents our results based on a static and dynamic analysis and discusses policy implications. Section 5 concludes the study.

\section{Description of Data}

Our dataset is composed of ten Asian economies: China, Hong Kong, Indonesia, India, the Republic of Korea (referred to as Korea), Malaysia, the Philippines, Pakistan, Singapore, and Thailand. Monthly 
exchange rate data from 2001:M01 to 2009:M12 has been taken from the IMF's International Financial Statistics database. Data on the Swiss franc $(\mathrm{CHF})$ and special drawing rights (SDR) have also been taken for the same time period to be used as the numeraire currency. For analysis purposes, each country is classified according to its de jure and de facto regimes, provided in Table 1. However, instead of using several categories, each country is placed in one of three broad categories: floating, managed float, and pegged. Crawling peg and currency board arrangements are both categorized as "pegged." The terms "floating," "free-floating," and "independently floating" are used interchangeably.

Table 1: Exchange rate regime classification in Asia [2001-2009]

\begin{tabular}{|c|c|c|}
\hline Country & De jure regime & De facto regime \\
\hline China & Managed floating & Crawling peg \\
\hline Hong Kong & Pegged & Currency board arrangement \\
\hline Indonesia & Floating & $\begin{array}{l}\text { Managed floating with no predetermined } \\
\text { path for the exchange rate }\end{array}$ \\
\hline India & Managed floating & $\begin{array}{l}\text { Managed floating with no predetermined } \\
\text { path for the exchange rate }\end{array}$ \\
\hline Korea & Floating & Independently floating \\
\hline Malaysia & Managed floating & $\begin{array}{l}\text { Managed floating with no predetermined } \\
\text { path for the exchange rate }\end{array}$ \\
\hline Philippines & Floating & Independently floating \\
\hline Pakistan & Floating & $\begin{array}{l}\text { Managed floating with no predetermined } \\
\text { path for the exchange rate }\end{array}$ \\
\hline Singapore & Managed floating & $\begin{array}{l}\text { Managed floating with no predetermined } \\
\text { path for the exchange rate }\end{array}$ \\
\hline Thailand & Managed floating & $\begin{array}{l}\text { Managed floating with no predetermined } \\
\text { path for the exchange rate }\end{array}$ \\
\hline
\end{tabular}

Source: IMF's de facto classification of exchange rate regimes and monetary policy frameworks at http://www.imf.org/external/np/mfd/er/2008/eng/0408.htm

\section{Methodology}

Identifying the true de facto exchange rate regime adopted by any country is not a trivial task and there are several ways of explaining the de facto practices of different countries. Keeping in view, however, the limited and specific nature of this study, we use the popular Frankel-Wei regression method to identify the implicit weights a country assigns to its probable currency basket, thus signaling its de facto exchange rate regime 
(see Frankel \& Wei, 1994, 1995, 2006). This can be explained with the help of the following equation:

$$
\Delta e_{t}^{i}=\alpha+\beta_{1} \Delta e_{t}^{\$}+\beta_{2} \Delta e_{t}^{€}+\beta_{3} \Delta e_{t}^{€}+\beta_{4} \Delta e_{t}^{¥}+\varepsilon_{t}
$$

where $\Delta e_{t}^{i}$ is the log difference of the exchange rate in the country's domestic currency and $e_{t}^{\$}, e_{t}^{£}, e_{t}^{€}$, and $e_{t}^{¥}$ represent the log of the US dollar, pound sterling, euro, and Japanese yen's exchange rates.

It is important to note that Frankel and Wei use the CHF as a base (numeraire) currency for calculating all exchange rates. However, some recent studies have used SDR and gold as a robustness test in response to the argument that the CHF is strongly correlated with the euro (Frankel \& Wei, 2007). The estimated coefficients in this equation $\beta_{1}, \beta_{2}, \beta_{3}$, and $\beta_{4}$ represent the implicit weight that each country assigns to the USD, GBP, EUR, and JPY on the basis of proportionate variations in the domestic currency explained by each of these benchmark currencies. However, the higher value of the estimated coefficient alone is not necessarily an indication of pegging since it may have resulted from the natural marketdriven correlation between two currencies. It is important to look at the significance of each coefficient as well as the overall variations explained (R-squared) by the regressor currencies to infer the de facto degree of pegging or flexibility (Baig, 2001).

\section{Results and Policy Implications}

\subsection{Static Analysis}

Table 2 presents two sets of OLS estimates obtained from equation (1) for each country. The first set is based on a regression where the CHF is used as the numeraire currency; in the second set, it is replaced by SDR. The US dollar seems to have an uncontestable influence over each currency irrespective of the choice of numeraire. However, a significant decrease in R-squared and either an entire shift in significance from the euro to the yen or an increase in the significance of the yen is often observed when the $\mathrm{CHF}$ is replaced by SDR. Due to these instabilities, further interpretations are based on the regression where the CHF is used as the numeraire.

China, Hong Kong, and Pakistan seem to be strongly pegged to the USD, which is the single-most highly significant currency and explains more than 95 percent of the variations for China and Hong Kong and 
almost 75 percent for Pakistan. India, Singapore, and Thailand seem to follow a basket peg where three out of four currencies are highly significant and explain at least 70 percent or more of the variation in their domestic exchange rates. Malaysia stands somewhere in the middle as two currencies, the USD and euro with their highly significant weights, explain almost 85 percent of the variation in the domestic currency. The Philippines also assigns significant weight to the USD and euro but the proportion of explained variation is relatively low at 65 percent. The Korean won and Indonesian rupiah are the least influenced by these benchmark currencies. In spite of the individual significance of the USD, euro, or pound, the four benchmark currencies explain only 37 percent of the variation for Korea and only 16 percent for Indonesia.

These findings are consistent with those of Rizvi, Bordes, and Naqvi (2012)-the authors disagree with the IMF's classification of Indonesia and the Philippines and provide strong evidence showing that Indonesia does not intervene in its exchange rate market or at least intervenes less than the Philippines. This also implies that, since the IMF has categorized the Philippines as a de facto "floating" regime, Indonesia should have been classified either under the same regime or as a more flexible regime. 
Table 2: Static estimates from Frankel-Wei regression

\begin{tabular}{|c|c|c|c|c|c|c|c|}
\hline Country & Reg. type & Constant & USD & GBP & EUR & JPY & $\begin{array}{c}\text { Adj. R- } \\
\text { sq. }\end{array}$ \\
\hline \multirow[t]{2}{*}{ China } & $\begin{array}{l}\text { CHF coef. } \\
\text { t-stat. }\end{array}$ & $\begin{array}{c}-0.00161^{* * *} \\
(-4.63)\end{array}$ & $\begin{array}{c}0.995896^{* * *} \\
(52.52)\end{array}$ & $\begin{array}{c}-0.036478^{*} \\
(-1.75)\end{array}$ & $\begin{array}{c}-0.020006 \\
(-0.57)\end{array}$ & $\begin{array}{c}-0.02264 \\
(-1.16)\end{array}$ & 0.978 \\
\hline & $\begin{array}{l}\text { SDR coef. } \\
\text { t-stat. }\end{array}$ & $\begin{array}{c}-0.00167^{* * *} \\
(-4.76)\end{array}$ & $\begin{array}{c}0.924904^{* * *} \\
\quad(23.12)\end{array}$ & $\begin{array}{c}-0.045163^{*} \\
(-1.77)\end{array}$ & $\begin{array}{c}-0.016221 \\
(-0.62)\end{array}$ & $\begin{array}{c}-0.01943 \\
(-0.901)\end{array}$ & 0.914 \\
\hline \multirow[t]{2}{*}{ Hong Kong } & $\begin{array}{c}\text { CHF coef. } \\
\text { t-stat. }\end{array}$ & $\begin{array}{c}-0.000016 \\
(-0.13)\end{array}$ & $\begin{array}{c}0.987115^{* * *} \\
\quad(151.22)\end{array}$ & $\begin{array}{c}-0.001456 \\
(-0.2023)\end{array}$ & $\begin{array}{c}-0.013543 \\
(-1.11)\end{array}$ & $\begin{array}{c}0.01314^{*} \\
(1.96)\end{array}$ & 0.997 \\
\hline & $\begin{array}{l}\text { SDR coef. } \\
\text { t-stat. }\end{array}$ & $\begin{array}{c}-0.000025 \\
(-0.21)\end{array}$ & $\begin{array}{c}0.986182^{* * *} \\
\quad(72.28)\end{array}$ & $\begin{array}{c}-0.000287 \\
(-0.03)\end{array}$ & $\begin{array}{l}-0.003038 \\
(-0.33896)\end{array}$ & $\begin{array}{c}0.01717^{* *} \\
(2.34)\end{array}$ & 0.9897 \\
\hline \multirow[t]{2}{*}{ Indonesia } & $\begin{array}{c}\text { CHF coef. } \\
\text { t-stat. }\end{array}$ & $\begin{array}{c}0.00252 \\
(0.78)\end{array}$ & $\begin{array}{c}0.358325^{* *} \\
\quad(2.04)\end{array}$ & $\begin{array}{c}0.081375 \\
(0.42)\end{array}$ & $\begin{array}{c}0.987^{* * *} \\
(3.02)\end{array}$ & $\begin{array}{c}-0.1294 \\
(-0.72)\end{array}$ & 0.166 \\
\hline & $\begin{array}{l}\text { SDR coef. } \\
\text { t-stat. }\end{array}$ & $\begin{array}{c}0.00252 \\
(0.781)\end{array}$ & $\begin{array}{c}-0.270413 \\
(-0.74)\end{array}$ & $\begin{array}{c}-0.046114 \\
(-0.197)\end{array}$ & $\begin{array}{c}0.192939 \\
(0.7998)\end{array}$ & $\begin{array}{c}-0.37988^{*} \\
(-1.93)\end{array}$ & 0.043 \\
\hline \multirow[t]{2}{*}{ India } & $\begin{array}{c}\text { CHF coef. } \\
\text { t-stat. }\end{array}$ & $\begin{array}{c}0.00023 \\
(0.17)\end{array}$ & $\begin{array}{c}0.684167^{* * *} \\
\quad(9.21)\end{array}$ & $\begin{array}{c}0.263455^{* * *} \\
\quad(3.23)\end{array}$ & $\begin{array}{c}0.43749^{* * *} \\
\quad(3.16)\end{array}$ & $\begin{array}{c}0.09432 \\
(1.23)\end{array}$ & 0.707 \\
\hline & $\begin{array}{l}\text { SDR coef. } \\
\text { t-stat. }\end{array}$ & $\begin{array}{c}0.000549 \\
(0.39)\end{array}$ & $\begin{array}{c}0.678939^{* * *} \\
\quad(4.22)\end{array}$ & $\begin{array}{c}0.207088^{* *} \\
(2.02)\end{array}$ & $\begin{array}{c}0.075706 \\
(0.72)\end{array}$ & $\begin{array}{c}-0.05117 \\
(-0.59)\end{array}$ & 0.193 \\
\hline \multirow[t]{2}{*}{ Korea } & $\begin{array}{c}\text { CHF coef. } \\
\text { t-stat. }\end{array}$ & $\begin{array}{c}0.000645 \\
(0.298)\end{array}$ & $\begin{array}{c}0.313147^{* * *} \\
\quad(2.65)\end{array}$ & $\begin{array}{c}0.403447^{* * *} \\
\quad(3.11)\end{array}$ & $\begin{array}{c}0.70885^{* * *} \\
\quad(3.22)\end{array}$ & $\begin{array}{c}-0.00665 \\
(-0.05)\end{array}$ & 0.3699 \\
\hline & $\begin{array}{l}\text { SDR coef. } \\
\text { t-stat. }\end{array}$ & $\begin{array}{c}0.001028 \\
(0.48)\end{array}$ & $\begin{array}{c}-0.09932 \\
(-0.41)\end{array}$ & $\begin{array}{c}0.229847 \\
(1.48)\end{array}$ & $\begin{array}{c}0.104233 \\
(0.65)\end{array}$ & $\begin{array}{c}-0.267306^{* *} \\
(-2.03)\end{array}$ & 0.1089 \\
\hline \multirow[t]{2}{*}{ Malaysia } & $\begin{array}{l}\text { CHF coef. } \\
\text { t-stat. }\end{array}$ & $\begin{array}{c}-0.00029 \\
(-0.36)\end{array}$ & $\begin{array}{c}0.803385^{* * *} \\
\quad(18.05)\end{array}$ & $\begin{array}{c}0.051305 \\
(1.05)\end{array}$ & $\begin{array}{c}0.19513^{* *} \\
(2.35)\end{array}$ & $\begin{array}{c}-0.044526 \\
(-0.97)\end{array}$ & 0.852 \\
\hline & $\begin{array}{l}\text { SDR coef. } \\
\text { t-stat. }\end{array}$ & $\begin{array}{c}-0.000301 \\
(-0.37)\end{array}$ & $\begin{array}{c}0.579935^{* * *} \\
\quad(6.32)\end{array}$ & $\begin{array}{c}-0.003202 \\
(-0.05)\end{array}$ & $\begin{array}{c}0.006914 \\
(0.11)\end{array}$ & $\begin{array}{c}-0.11296^{* *} \\
(-2.29)\end{array}$ & 0.444 \\
\hline \multirow[t]{2}{*}{ Philippines } & $\begin{array}{c}\text { CHF coef. } \\
\text { t-stat. }\end{array}$ & $\begin{array}{c}-0.00025 \\
(-0.152)\end{array}$ & $\begin{array}{c}0.871139^{* * *} \\
\quad(9.92)\end{array}$ & $\begin{array}{c}-0.045055 \\
(-0.47)\end{array}$ & $\begin{array}{c}0.43259^{* * *} \\
\quad(2.64)\end{array}$ & $\begin{array}{c}0.002329 \\
(0.026)\end{array}$ & 0.6375 \\
\hline & $\begin{array}{l}\text { SDR coef. } \\
\text { t-stat. }\end{array}$ & $\begin{array}{l}-0.00011 \\
(-0.0698)\end{array}$ & $\begin{array}{c}0.643005^{* * *} \\
\quad(3.49)\end{array}$ & $\begin{array}{c}-0.124446 \\
(-1.060107)\end{array}$ & $\begin{array}{l}0.038673 \\
(0.31947)\end{array}$ & $\begin{array}{c}-0.141788 \\
(-1.43)\end{array}$ & 0.2001 \\
\hline \multirow[t]{2}{*}{ Pakistan } & $\begin{array}{c}\text { CHF coef. } \\
\text { t-stat. }\end{array}$ & $\begin{array}{c}0.00398^{* * *} \\
(3.42)\end{array}$ & $\begin{array}{c}0.911517^{* * *} \\
\quad(14.35)\end{array}$ & $\begin{array}{c}-0.038313 \\
(-0.548994)\end{array}$ & $\begin{array}{c}0.088501 \\
(0.747928)\end{array}$ & $\begin{array}{c}-0.098879 \\
(-1.51)\end{array}$ & 0.756 \\
\hline & $\begin{array}{l}\text { SDR coef. } \\
\text { t-stat. }\end{array}$ & $\begin{array}{c}0.00393^{* * *} \\
\quad(3.42)\end{array}$ & $\begin{array}{c}0.814724^{* * *} \\
\quad(6.22)\end{array}$ & $\begin{array}{c}-0.03385 \\
(-0.405707)\end{array}$ & $\begin{array}{c}0.136077 \\
(1.581589)\end{array}$ & $\begin{array}{c}-0.080413 \\
(-1.14)\end{array}$ & 0.376 \\
\hline \multirow[t]{2}{*}{ Singapore } & $\begin{array}{l}\text { CHF coef. } \\
\text { t-stat. }\end{array}$ & $\begin{array}{c}-0.0005 \\
(-0.65)\end{array}$ & $\begin{array}{c}0.52609^{* * *} \\
(12.36)\end{array}$ & $\begin{array}{c}0.06109 \\
(1.31)\end{array}$ & $\begin{array}{c}0.40939^{* * *} \\
\quad(5.16)\end{array}$ & $\begin{array}{c}0.12838^{* * *} \\
\quad(2.93)\end{array}$ & 0.7996 \\
\hline & $\begin{array}{l}\text { SDR coef. } \\
\text { t-stat. }\end{array}$ & $\begin{array}{c}-0.00048 \\
(-0.602)\end{array}$ & $\begin{array}{c}0.23157^{* *} \\
(2.61)\end{array}$ & $\begin{array}{c}-0.01255 \\
(-0.22)\end{array}$ & $\begin{array}{c}0.065937 \\
(1.13)\end{array}$ & $\begin{array}{c}0.00824 \\
(0.17)\end{array}$ & 0.055 \\
\hline \multirow[t]{2}{*}{ Thailand } & $\begin{array}{c}\text { CHF coef. } \\
\text { t-stat. }\end{array}$ & $\begin{array}{c}-0.0013 \\
(-1.23)\end{array}$ & $\begin{array}{c}0.47809^{* * *} \\
\quad(8.22)\end{array}$ & $\begin{array}{c}0.17798^{* * *} \\
(2.79)\end{array}$ & $\begin{array}{c}0.163956 \\
(1.51)\end{array}$ & $\begin{array}{c}0.268569^{* * *} \\
(4.49)\end{array}$ & 0.702 \\
\hline & $\begin{array}{l}\text { SDR coef. } \\
\text { t-stat. }\end{array}$ & $\begin{array}{l}-0.0013 \\
(-1.197)\end{array}$ & $\begin{array}{c}0.30961^{* *} \\
(2.57)\end{array}$ & $\begin{array}{c}0.117691 \\
(1.53)\end{array}$ & $\begin{array}{c}-0.04411 \\
(-0.56)\end{array}$ & $\begin{array}{c}0.186971^{* * *} \\
\quad(2.88)\end{array}$ & 0.134 \\
\hline
\end{tabular}




\subsection{Time-Varying (Dynamic) Assessment}

For a deeper insight into how the influence of benchmark currencies over Asian currencies has evolved over the period under study, we augment the static Frankel-Wei estimates by calculating recursive OLS estimates. Recursive time-varying estimates are obtained through iterative estimations of the same regression presented in equation (1), where the sample size is increased by 1 in every iteration. These estimates help analyze the dynamic trend in the benchmark currency weighting that each country applies while determining the value of its own currency.

Figure 1 shows that, for China and Hong Kong, despite some variations, the USD remains the sole anchor even after 2005 when China announced it would follow a managed floating regime. There is some degree of substitution of the EUR for the USD in China immediately after 2005, but the dollar regains its weight during 2007-08.

\section{Figure 1: Recursive coefficients from Frankel-Wei regression, China and Hong Kong}

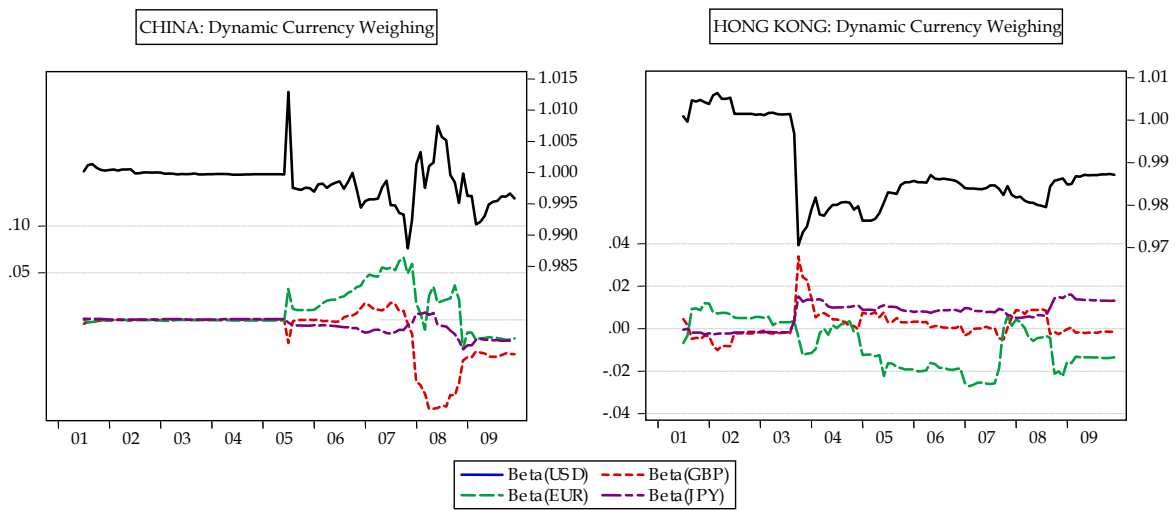

Figure 2 suggests that both the Philippines and Pakistan are also strongly influenced by the USD. However, unlike China and Hong Kong, they exhibit a very smooth pattern in dynamic estimates of all the anchor currencies. Indeed, the observed pattern indicates de facto pegging with very minor fluctuations at the end of the sample period. These fluctuations could be a natural outcome of increasing concerns about the weakening dollar following the negative impact of the subprime crisis in the US. 
Figure 2: Recursive coefficients from Frankel-Wei regression, the Philippines and Pakistan

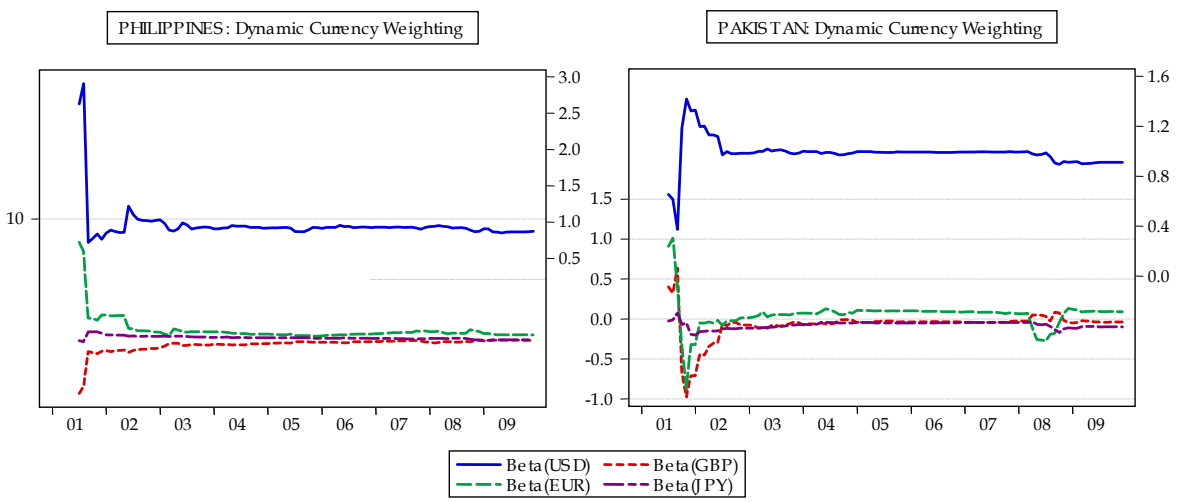

According to Figure 3, India seems to have been inclined toward the EUR since its inception while the USD's influence over the Indian rupee started to decline in 2002 with a moderate increase in the weight of the EUR. During this nine-year period, almost 40 percent of the USD's share moved toward other currencies with the EUR being a significant recipient. Exactly the same has happened in Malaysia but over significantly less time and at a faster pace: at times, the USD and EUR weights seem equivalent.

Figure 3: Recursive coefficients from Frankel-Wei regression, India and Malaysia

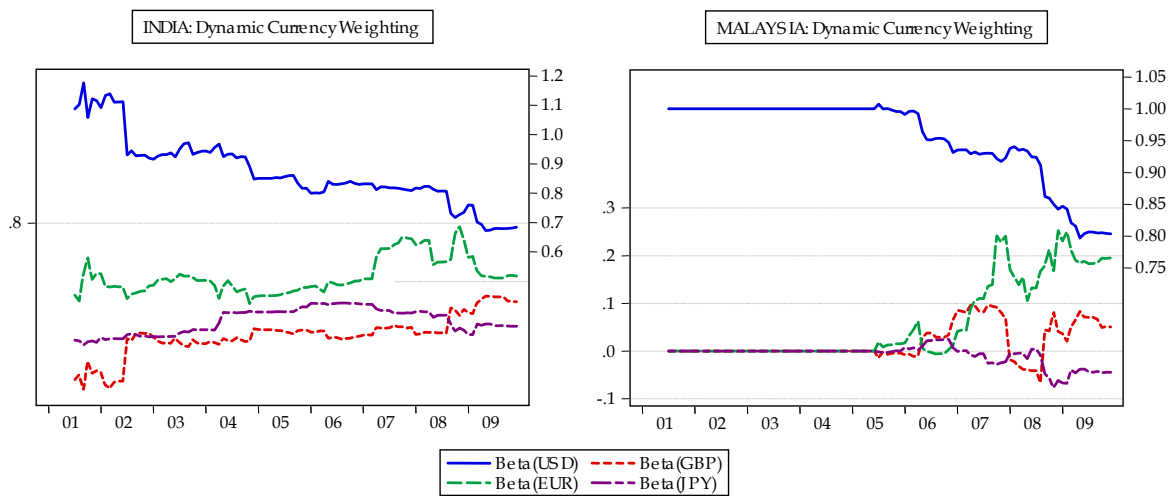

Figures 4 and 5 show that Singapore, Thailand, Indonesia, and Korea have relied on at least two or more currencies, negating the assumption of a hard peg with the USD. For Singapore and Thailand, the USD weight is round 0.5 on average over the whole sample period; for Indonesia and Korea, it is even less (approx 0.35) with positive weights allocated to at least two other benchmark currencies on a consistent basis. 
Figure 4: Recursive coefficients from Frankel-Wei regression, Singapore and Thailand

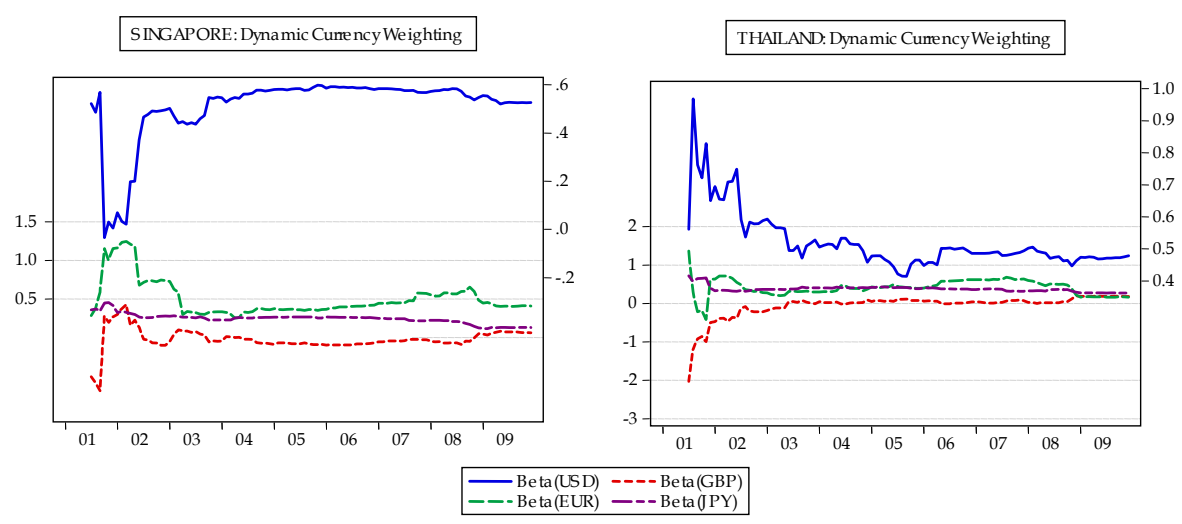

Figure 5: Recursive coefficients from Frankel-Wei regression, Indonesia and Korea

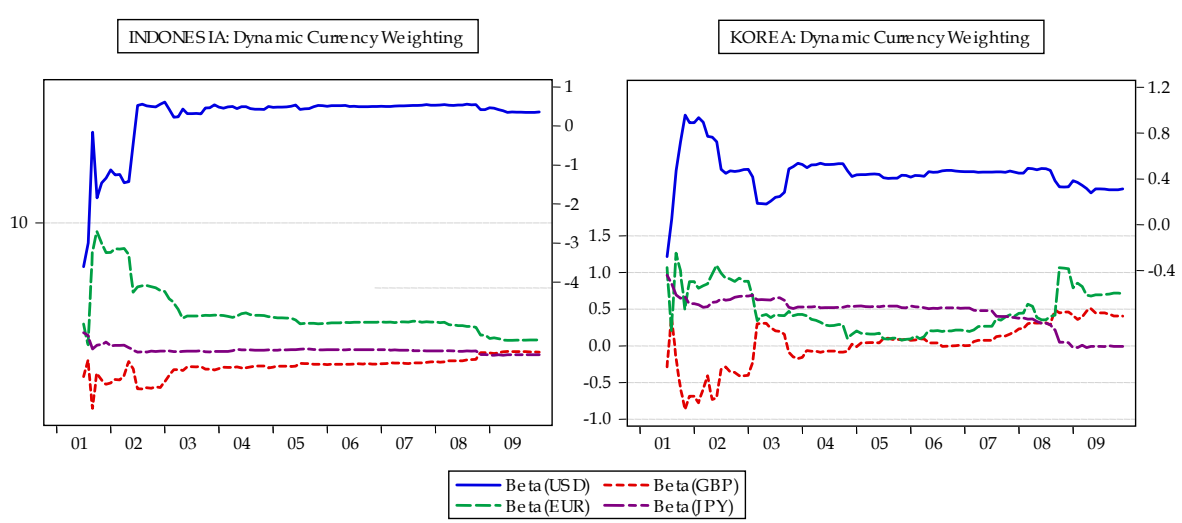

The anchoring of domestic currencies to multiple anchors may be an indication of a basket peg in the case of Singapore and Thailand because the proportion of explained variations in the domestic currency is about 70 percent. However, as for Indonesia and Korea, this proportion is only 16 and 36 percent, respectively, suggesting the existence of a market-driven natural correlation between the domestic currencies and benchmark currencies, thus precluding any possibility of a basket peg.

\section{Conclusion}

Applying a static and then dynamic Frankel-Wei analysis, we have assessed the degree and time-varying behavior of currency pegging for a selected sample of ten Asian economies. According to the results, the USD is 
the first choice of a de facto peg for many countries, including China, Hong Kong, the Philippines, and Pakistan. The other countries in our sample, except Korea and Indonesia, seem to have adopted a basket peg of two or more currencies with a rapidly increasing weight assigned to the euro.

The small R-squared term in the regression for Indonesia seems to imply that it is paying the penalty for some flaw in the IMF's methodology by being categorized as a managed float contrary to its de jure claim of being free-floating. On the other hand, the Philippines seems to be in an advantageous position as the IMF agrees with its de jure claim of being a free floater despite the fact that its real practices clearly indicate significant pegging to the basket of four currencies. 


\section{References}

Baig, T. (2001). Characterizing exchange rate regimes post-crisis East Asia (Working Paper No. 01/152) Washington, DC: International Monetary Fund.

Bracke, T., \& Bunda, I. (2011). Exchange rate anchoring: Is there still a de facto US dollar standard? (Working Paper No. 1353). Frankfurt, Germany: European Central Bank.

Bubula, A., \& Otker-Robe, I. (2003). Are pegged and intermediate exchange rate regimes more crisis-prone? (Working Paper No. 03/223). Washington, DC: International Monetary Fund.

Dueker, M. J., \& Fischer, A. M. (2001). The mechanics of a successful exchange rate peg: Lessons for emerging markets. Federal Reserve Bank of St. Louis Review, 83(5), 47-56.

Frankel, J. (1993). Is Japan creating a yen bloc in East Asia and the Pacific? In J. Frankel \& M. Khaler (Ed.), Regionalism and rivalry: Japan and the US in Pacific Asia. Chicago, IL: University of Chicago Press.

Frankel, J., \& Wei, S.-J. (1994). Yen bloc or dollar bloc? Exchange rate policies of the East Asian economies. In T. Ito \& A. O. Krueger (Eds.), Macroeconomic linkages: Savings, exchange rates and capital flows. Chicago, IL: University of Chicago Press.

Frankel, J., \& Wei, S.-J. (1995). Emerging currency blocs. In D. H. Genberg (Ed.), The international monetary system; Its Institution and its future, 111-143. Berlin, Germany: Springer.

Frankel, J., \& Wei, S.-J. (2006). Currency mysteries (Mimeo). Retrieved from http://www.hks.harvard.edu/fs/jfrankel/CurrencyMysteriesRM B5-29-06.pdf

Frankel, J., \& Wei, S.-J. (2007). Assessing China's exchange rate regime. Economic Policy, 22(7), 575-614.

Husain, I. (2005, November). What works best for emerging market economies? Keynote address at the State Bank of Pakistan's Conference on Monetary-cum-Exchange Rate Regime, Karachi. 
Mishkin, F. S. (1998). Exchange-rate pegging in emerging market countries? (Mimeo). Retrieved from http://citeseerx.ist.psu.edu/viewdoc/ download?doi=10.1.1.199.769\&rep=rep1\&type $=p d f$

Plümper, T., \& Neumayer, E. (2008). Exchange rate regime choice with multiple key currencies (Political Science and Political Economy Working Paper No. 5/2008). London, UK: London School of Economics and Political Science.

Rizvi, S. K., Bordes, C., \& Naqvi, B. (2012). Reassessment of exchange rate flexibility and fear of floating in Asia: How much credible are the benchmark floaters? (Mimeo). Retrieved from http://www.alde.es/encuentros/anteriores/xiveea/trabajos/k/p df/041.pdf

Velasco, A. (1999). Exchange rate policies for developing countries: What have we learned? What do we still not know? Paper prepared for the Group of 24. Retrieved from http://www.hks.harvard.edu/fs/drodrik/ Research\%20papers/velasco.pdf 